\title{
Coronavirus: notes on crisis, borders and the future of neoliberalism
}

\begin{abstract}
Josep Maria Antentas
Centre d'Estudis Sociològics sobre la Vida Quotidiana i el Treball (QUIT) - Institut d'Estudis del Treball (IET), Department of Sociology at the Universitat Autònoma de Barcelona (UAB), Barecelona, Spain

Correspondence: Josep Maria Antentas (josepmaria.antentas@uab.cat)

Received: 26 September 2020 - Revised: 23 October 2020 - Accepted: 26 October 2020 - Published: 7 December 2020

Abstract. Every crisis is a moment both of the intensification of borders (social, economic, geographical...) and of their potential breaking down - a moment of the reaffirmation of a certain social model and of its questioning. Borders have acquired centrality in the imaginary of the management of the pandemic. They are a constitutive part of the pandemic condition, endowed with a new symbolic and cognitive force. The new importance of borders in times of a pandemic also shows the complexity of the concept of border itself and accelerates the trends underway regarding borders' transformations. The pandemic draws a new strategic border space and accentuates the complexity of the relationship between sovereignty and territory inherent to the process of globalization. The massive interventions by states to shore up the economy and support businesses and workers have the goal of stabilizing the economy, without any intention of entering into a logic of redistribution and expansion of public services. These massive bailouts may simply be the prelude to a more virulent phase, where a crisis of legitimacy and a crisis of social reproduction and of the global forms of governance of neoliberalism are interwoven. The contradiction between the free movement of capital and goods and the limited movement of labor that characterizes globalization can be further intensified, while the rhetoric of borders and control takes on new relevance.
\end{abstract}

\section{Introduction}

"Many people blame the Coronavirus epidemic on globalization, and say that the only way to prevent more such outbreaks is to de-globalize the world" wrote Noah Harari (2020) in a disapproving tone at the beginning of the pandemic. For him it was wrong to blame globalization for the current pandemic, since in the past humanity has already faced other and more deadly crises of this kind: "Epidemics killed millions of people long before the current age of globalization. In the 14th century there were no airplanes and cruise ships, and yet the Black Death spread from East Asia to Western Europe in little more than a decade. It killed between 75 million and 200 million people - more than a quarter of the population of Eurasia" (Harari, 2020).

His thesis attempts to disconnect the pandemic and global capitalism. There is no doubt that pandemics have occurred throughout history, having a close relationship with urbanization, trade and wars. But one thing is to see that pandemics are inherent in human history and the other is not to see how the conditions of gestation and propagation of the COVID-19 pandemic concretely relate to neoliberal globalization.

\section{A globalization pandemic}

Contrary to Harari's theses, the current pandemic is undoubtedly the daughter of globalization and neoliberalism and their particular spatial and temporal configurations. It is so in several ways.

First, COVID-19 is part of a historical acceleration of pandemics as a result of environmental degradation. Mike Davis (2006) and Robert Wallace, in his work alone or with other collaborators (Wallace, 2016; Wallace and Wallace, 2016; Wallace et al., 2020), have pointed out the connections between global health and neoliberalism. Their research focuses on the economic, environmental and spatial structural conditions that explain the emergence of pandemics. Deforestation, destruction of the natural habitat of 
wild animal species and the impact of agrobusiness have played a decisive role in the multiplication of zoonoses in recent decades. Deforestation, parallel to peri-urbanization, reduces the distances between human populations and the wild viruses that were locked up in the tropical forests. Meanwhile, agrobusiness leads to large-scale hyper-concentration and uniformity of animals, weakening their immune system and the firewalls that slow down the transmission of pathogens. The permanent renovation of the stock and the increase in the geographical scope of industrial farming amplifies and speeds up the circulation and evolution of pathogens. The current pandemic is part of the broader process of ongoing global ecological crisis and reinforces the need to understand human health in interaction with natural ecosystems, as does the discipline of planetary health itself (Ostfeld, 2017).

Secondly, the geography of its expansion is related to the main economic poles and globalized cities, as Kim Moody (2020) has shown. Significantly, the COVID19 reached the European Union (EU) through the circuits of the international economy, its value chains and just-intime logistics. The mobility of commodities runs parallel to a global mobility of certain segments of people (business people, tourists...) that has become naturalized and rendered invisible, as Adia Benton (2020) points out. It is instructive that the virus arrived in Europe through the production and logistic circuits of global capitalism and not through the refugees who arrive at its shores. This does not detract from the fact that, in the end, a real catastrophe also developed in the refugee camps once, inevitably, the virus entered them (Godin, 2020).

Thirdly, the pandemic has acquired a properly planetary scope (still unevenly) and has not been limited merely to certain regions, as was the case with some of the great pandemics of the past - i.e., the Black Death in the 14th century, centered in Europe, the Mediterranean and the Middle East. Its geography is that of a globalized economic and trade system.

Fourth, the very speed of its spread is a result of the speed of trade, and the movement of goods and people under global capitalism. In fact, even supporters of the global capitalist model such as Yossi Sheffi (2017) have pointed out how the global economy is vulnerable to the logic of contagion (whether financial, health, or other). Indeed, the history of the spread of cross-border pandemics shows a pattern of historical acceleration in line with the intensification of economic exchange and growing interdependence.

Finally, the deadly capacity of the COVID-19 is related to health pathologies typical of contemporary capitalism, such as pollution, or obesity due to unhealthy eating. It must therefore be linked to a broader public health crisis linked to a certain social model based on the widespread commodification of social relations and an unbalanced relationship with natural ecosystems. In this sense, the urban lockdown itself has brought to light such diverse issues as the weakening of public health systems after decades of neoliberal policies and the lack of regular contact with the natural environment that the inhabitants of large urban concentrations live in.

For this set of reasons it is convenient not to analyze the COVID-19 crisis as the result of an exogenous element (although in a superficial sense the virus is) but as a crisis caused by the eco-social contradictions of neoliberal globalization. For this reason, its outbreak, however spectacular it may have been, cannot be considered a surprising element, but rather a catastrophe foretold - a catastrophe the possibility of which was warned of by multiple agencies, among them the Pentagon itself in its January 2017 report, "USNORTHCOM Branch Plan 3560: Pandemic Influenza and Infectious Disease Response" (Klippenstein, 2020). Since the outbreak of avian flu in 1997 in Hong Kong, western governments developed national strategies to prepare for future pandemics, although they were insufficient. In the case of the United States, for example, a 2016 report by national security analyst Christopher Kirchhoff (2016) noted, in light of the recent experience of the Ebola outbreak in West Africa, major gaps in pandemic preparedness. The Obama administration launched a Directorate for Global Health Security and Biodefense within the National Security Council, dismantled in 2018 by the Trump administration. From this point of view, the most tragic aspect of the current situation is not only the gravity of the situation but, as Simon Critchley (2020) has pointed out, the very fact that it was known that it would happen.

Every crisis acts as a clarifier of social reality, showing truths that are usually hidden. "Border" and "crisis" are two concepts that present some analogies that help to understand each other. Borders are spaces of exclusion, a limit space that marks a constituent outside, often a terra incognita. But they are also territories of hybridization and politicalcultural crossbreeding. This double character of the spatiality of the border can be related to the temporal characteristics of every situation of crisis. An analogy can be established between the spatiality of the border and the temporality of the crisis. A crisis marks a turning point, a division between two periods, an end of stage to enter a potential unknown territory. It also marks a moment of connection between the real present and a possible future, a moment of opening of the possible. Crises are also a frontier time, between an agonizing reality and another to come, while borders are usually a space of crises.

Every crisis is a moment both of the intensification of borders (social, economic, geographical...) and of their potential breaking down - a moment of the reaffirmation of a certain social model and of its questioning. Crises allow us to extend the frontiers of what is possible and to think at new horizons, while at the same time they entail the threat of an involution and a closing of expectations. They are moments of clarification of social relations showing what in times of normality is not always perceptible. A concrete example, referring to borders, has been the temporal and geopolitical partial inversion of border patterns of population control, 
with countries of the global south decreeing a ban on the entry into their countries of travelers from the European Union, once the latter proved to be one of the epicenters of the pandemic. This episode is undoubtedly transitory and does not imply any structural change in border policy or in the differential population mobility of globalization. But it has the pedagogical virtue of bringing the real meaning of border and control policies affecting the bulk of the world's population in normal times relatively close to the heart of the western world (Borriello and Salihoglu, 2020).

"The Great Lockdown", as the IMF (2020) itself has called the present crisis, has reflected the vulnerability of global capitalism and the fragility of existence. It has brought to the heart of the western world, and its middle class, a feeling of unknown health insecurity, breaking the illusory sense of being on the sidelines of the public health catastrophes that have repeatedly affected the global south. Globalization built what Andersson (2019) has called a "No Go World", based on a global geography of fear, focused by illusory remote areas of insecurity. The pandemic modifies this geography of fear, simultaneously reinforcing the sense of external and internal danger and bringing the danger closer to the door. The spread of the virus across the planet and into the heart of the western world constitutes a socio-health boomerang effect, a globalization boomerang, which presents analogies with the colonial and imperial boomerang effect, analyzed by Hannah Arendt (2017 [1951]) many decades ago in pointing out how the practices of European colonial racialization and territorialization prepared the ground for the emergence of fascism in Europe.

The pandemic has shaken the symbolic, cultural and psychological borders behind which a false sense of security was built. From this point of view, the hardships of lockdown, fear, insecurity ..., which have been lived as extraordinary, constitute, for various reasons, the ordinary life of a very important part of humanity. What has been experienced is, therefore, both extraordinary and ordinary, recalling in some way Walter Benjamin's (1940) old statement that "The tradition of the oppressed teaches us that the 'emergency situation' in which we live is the rule" - not in the sense of not knowing how to distinguish crises from normal moments or to dissolve the very idea of crisis into a pathological normality, but in the sense of remembering the harshness of the daily life of millions of people under global capitalism.

\section{The borders of the pandemic}

The response of governments, within the existing wide variety of attitudes (from the denial à la Trump, to the total lockdown of many European and Latin American countries, or to the electronic tracking policies of some Asian countries), has been contradictory and not always coherent. But border closure has been a universal practice. The pandemic has led to a new prominence of borders (Wille and Kanesu, 2020). Bor- ders have acquired centrality in the imaginary of the management of the pandemic. They are a constitutive part of the pandemic condition, endowed with a new symbolic and cognitive force. Throughout history, border closure has been a constant during pandemics and, in fact, disease control was one of the first reasons in the modern world to justify border controls (Kenny, 2000).

The closure of borders, both in its real and ideological dimension, has in part attempted to defensively replace the very lack of coordination and capacity for joint international action shown by states. They have been, as Byung-Chul Han (2020) remarked, a "desperate expression of sovereignty" but at the same time they reflect the global failure of the policies implemented. The closing of borders serves to transmit an (illusory) image of control, facilitates the biopolitical management of the crisis and, in the case of governments like Trump's, fosters a nationalist discourse that presents the virus as an external threat (Brown, 2020). In reality, the denomination of the virus as "Wuhan virus" or "Chinese virus" represents a sort of linguistic bordering (Nossem, 2020a) aimed at presenting the virus as foreign and beyond national borders. This connects with a long tradition of scapegoating in times of pandemics, such as that of the Jews during the Black Death, usually along racial and national lines.

The closure of borders, as Nossem (2020b) points out, not only implies a policy focus on the national arena but also a limited vision of the national itself. It draws a schematic inside-out imaginary that considers the national as something that can be isolated from the outside. It projects a simplistic and straightforward image, analogous to the walling process that has gained strength in recent decades, marking a symbolic but illusory crystal-clear inside-out and them-us, as Wendy Brown (2010) has shown. There is also an analogy between the fortress mentality of closing borders and the social fear of certain social groups during the pandemic (Liu and Bennett, 2020) as pandemics reinforce a vision of the world were boundaries between people to strengthen. The logic of closing external borders is complemented by a logic of internal social stratification in which the very concept of "social distance" can be reframed as social and spatial fortification of the most privileged groups.

In reality, behind this schematic image of fortification produced by border closure, the new importance of borders in times of pandemic also shows the complexity of the concept of border itself and accelerates the trends underway. According to Shachar $(2020 \mathrm{a}, \mathrm{b})$ the border undergoes a mutation in its form: it goes beyond being a mere dividing line of a territory, extending to its interior and exterior, becoming a "shifting border" - that can escape through space and unfolds at various points and scales, combining static and dynamic aspects. Walling and shifting border dynamics are two parallel and overlapping processes whose recombined logic is deepened. 
The transformations of the border and its acceleration during the pandemic draw a new strategic border space and highlight the political and strategic character of the construction of the space itself, as Kristin Ross (1989) classically analyzed. At the same time, they accentuate the complexity of the relationship between sovereignty and territory inherent to the process of globalization. They show in a broader sense the multiplicity and heterogeneity of the very concept of border, pointed out by Étienne Balibar (2002) in a context of multiplication of borders in today's world. This process runs parallel to the growing heterogeneity of the semantic field of the concept of border itself (Mezzarda and Neilson, 2013).

\section{The fate of neoliberalism}

The paradox of the current crisis is that it is the result of conscious, but undesired, decisions by governments to stop production. States were forced to act against their will, albeit knowing the impact that the lockdown would have on the economy, for fear of losing legitimacy if the health situation went out of control and for fear that in the end the costs could be worse if the pandemic situation was prolonged. Lockdown was adopted as the lesser evil in the absence of other alternatives. In this way we have witnessed a particular reformulation of the classic tension between accumulation and legitimation identified by O'Connor (1979) in the seventies. For him the state had two potentially contradictory types of intervention: to legitimize the system to the masses and to guarantee accumulation. For decades neoliberalism fostered measures favorable to accumulation which, in the end, weakened its legitimacy, while in the current crisis, to maintain legitimacy the states had to take measures that were detrimental, in the short term, to the accumulation of capital.

Undoubtedly, once this path was adopted there has been attempts to exploit the situation (which vary according to the socio-political context of each country), by appealing to national unity with patriotic rhetoric, legitimizing the armed forces through their tasks of civilian assistance, and standardizing new electronic surveillance techniques that will have more future uses than health care.

The current crisis erupts after a decade of political-cultural erosion of neoliberalism and in a context of increasing internal tensions of globalization, geopolitical friction and disagreements between elites. The framing of an exculpatory narrative of globalization is not as mechanical as in 2008, and the problems of legitimacy of political power are greater. As in 2008, many voices have pointed to the end of neoliberalism. Even from the economic and political establishment itself, many statements have been made about the need for a change of course. Does this mean that we are facing the end of neoliberalism and the return of a kind of Keynesianism?

The massive interventions by the states to shore up the economy and support businesses and workers are in reality a kind of what can be called transitory instrumental emer- gency Keynesianism to stabilize the system, without any intention of entering into a logic of redistribution and expansion of public services (which does deny the fact that the relegitimization of public health care will make privatization policies more difficult). More than a redistributive reorganization, the measures carried out by the different governments have consisted of intervening temporarily to sustain the economy and avoid its collapse, in particular to support businesses, but without altering the basic coordinates of the neoliberal model - a kind of inverted upwards Keynesianism. They will probably seek to reorganize the chains of global production for the benefit of a greater autonomy of the states in strategic selective questions (i.e., sanitary material) but without reverting the process of socio-political disorganization of the working class and loss of trade union bargaining power propitiated by globalization.

If the neoliberal theses prevail, this second wave of massive bailouts to sustain the economy, after the first one in 2008 oriented to the financial system, may simply be the prelude to a more virulent phase, where a crisis of legitimacy and a crisis of social reproduction and of the global forms of governance of neoliberalism are interwoven. This would imply a hardened neoliberalism, where climate instability, increasing authoritarian interventions in domestic politics and recurrent border crises (such as the migratory crises that have brought the border regime of the European Union into crisis since 2015) are combined - in the midst of greater geopolitical tensions and growing fractures between different fractions of the political and financial elites.

The contradiction between the free movement of capital and goods and the limited movement of labor that characterizes globalization can be further intensified, while the rhetoric of borders and control takes on new relevance largely because of the need for states to project a sense of control and authority in an increasingly interdependent and vulnerable world and because of inter-state power struggles. The role of the border in the production of the heterogeneous time and space of global capitalism (Mezzarda and Neilson, 2013) may become even more acute. The hardening in recent months of the external regime borders of the European Union, accelerating a process begun in 2015 , is a good example (Philip, 2020) - the history of border control during pandemics showing that the extraordinary policy of restrictions is often prolonged after them (Kenny, 2020).

A scenario, in short, where the space and time discordances (to use the terminology of Daniel Bensaïd, 1997) of neoliberal globalization explode even more. Space discordances, in the sense that globalization has led to an internationalization of production and value chains, while the world remains politically structured around national states and national social formations. Time discordances, in the sense that in the current multidimensional crisis opposing temporal logics operate, where the immediacy of financial interests, the short-termism of parliamentary politics and political elites, or the long temporalities of the ecological crisis collide. 


\section{Afterlife neoliberalism}

We can consider ours to be the time of the historical decline of neoliberalism, an epoch of what some have called "zombie neoliberalism" (Fisher, 2013; Peck, 2010). Perhaps it is even better to call it afterlife neoliberalism. The present moment can be read as an interregnum, in the Gramscian sense of the term. One era is running out and another uncertain one is yet to come. The post-crisis world will be the result of the balance of forces, in its dual national and international dimensions, between the various socio-political projects/blocks in play. Every crisis ends with a process of reorganization of social and geopolitical relations whose final outcome is the result of the social and political collisions that take place during it. The paradox of the current situation is that a deep crisis of legitimacy of global capitalism coexists simultaneously with a structural weakness of the anti-neoliberal progressive forces, albeit with some successes, in a context of growing reactionary alternatives. Suffering from deep ideological and cultural discredit the fate of neoliberalism is not yet politically settled.

Data availability. All the data used in the article can be accessed through the references.

Competing interests. The author declares that he has no conflict of interest.

Review statement. This paper was edited by Benedikt Korf and reviewed by one anonymous referee.

\section{References}

Andersson, R.: No Go World. How Fear Is Redrawing Our Maps and Infecting Our Politics, University of California Press, Berkeley, 2019.

Arendt, H.: The Origins of Totalitarianism, New York, Penguin, New York, 2017 [1951].

Balibar, E.: Politics and the Other Scene, Verso, London, 2002.

Benjamin, W.: On the concept of History, Marxists.org, available at: https://www.marxists.org/reference/archive/benjamin/ 1940/history.htm (last access: 9 October 2020), 1940.

Bensaïd, D.: Le pari mélancolique, Fayard, Paris, 1997.

Benton, A.: Border Promiscuity, Illicit Intimacies, and Origin Stories: Or what Contagion's Bookends Tell us About New Infectious Diseases and a Racialized Geography of Blame, Somatosphere, availabel at: http://somatosphere.net/ forumpost/border-promiscuity-racialized-blame/, last access: 6 March 2020.

Borriello, G. and Salihoglu, A.: Borders in the Time of Coronavirus: How the COVID-19 Pandemic Upended the Global Mobility Paradigm, Compas, available at: https://www.compas.ox.ac.uk/2020/borders-in-the-time- of-coronavirus-how-the-covid-19-pandemic, last access: 3 March 2020

Brown, W.: Walled States, Waning Sovereignty, Zone Books, New York, 2010.

Brown, W.: A Worldwide Mutual Pact, The Drift, available at: https: //www.thedriftmag.com/a-worldwide-mutual-pact/, last access: 24 June 2020.

Critchley, S.: La tragedia es que sabíamos que esto iba a pasar, El confidencial, 22 April 2020.

Davis, M.: The Monster at Our Door, Holt Paperbacks, New York, 2006.

Fisher, M.: How to kill a zombie: strategizing the end of neoliberalisme, OpenDemocracy, 18 July 2013.

Godin, M.: COVID-19 Outbreaks Are Now Emerging in Refugee Camps. Why Did it Take so Long For the Virus to Reach Them?, Time, available at: https://time.com/5893135/ covid-19-refugee-camps/, last access: 9 October 2020.

Han, B.-C.: The viral emergency and the world tomorrow, El Pais, 22 March 2020.

Harari, N.: In the Battle Against Coronavirus, Humanity Lacks Leadership, Time, 15 March 2020.

International Monetary Fund: World Economic Outlook: The Great Lockdown, Washington, April 2020.

Kenny, C.: Pandemics Close Borders - And Keep Them Closed, Politico, available at: https://www.politico.com/news/magazine/ 2020/03/25/trump-coronavirus-borders-history-plague-146788, last access: 25 March 2020.

Kirchhoff, C.: Memorandum for ambassadoor Susan E. Rice, Washington, available at: https://int.nyt.com/data/documenthelper/ 6823-national-security-counci-ebola/05bd797500ea55be0724/ optimized/full.pdf\#page=1, last access: 11 July 2016.

Klippenstein, K.: Exclusive: The Military Knew Years Ago That a Coronavirus Was Coming, The Nation, 1 April 2020.

Liu, X. and Bennett, M.: Viral borders: COVID-19's effects on securitization, surveillance, and identity in Mainland China and Hong Kong, Dialog. Human Geogr., 10, 158-163, 2020.

Mezzarda, S. and Neilson, B.: Border ad Method, or, the Multiplication of Labor, Duke University Press, Durham, 2013.

Moody, K.: How "Just-in-Time" Capitalism Spread COVID19, Spectre Journal, available at: https://spectrejournal.com/ how-just-in-time-capitalism-spread-covid-19/, last access: 8 April 2020.

Nossem, E.: Linguistic rebordering: Constructing COVID-19 as an external threat, Bord. Perspect., 4, 77-80, 2020a.

Nossem, E.: The pandemic of nationalism and the nationalism of pandemics, UniGR-CBS Working Paper 8, https://doi.org/10.25353/ubtr-xxxx-1073-4da7, 2020b.

O'Connor, J.: The Fiscal crisis of the State, Transaction Publishers, London, 1979 (1973).

Ostfeld, R.: Biodiversity loss and the ecology of infectious disease, Lancet, 1, E2-E3, 2017.

Peck, J.: Zombie neoliberalism and the ambidextrous State, Theor. Crimonol., 14, 104-110, 2010.

Pentagon: USNORTHCOM Branch Plan 3560: Pandemic Influenza and Infectious Disease, Response, Washington, 6 January 2017.

Philip Naceur, S.: COVID-19 Is Grist to the Border Regime Mill, Rosa Luxemburg Stiftung, available at: https://rosaluxna.org/ publications/covid-19-is-grist-to-the-border-regime-mill/, last access: July 2020. 
Ross, K.: The Emergence of Social Space, University of Minnesota Press, Minnesota, 1989.

Shachar, A.: The shifting border: Legal cartographies of migration and mobility, Manchester University Press, Manchester, 2020a.

Shachar, A.: Borders in the time of COVID19, Ethics \& International Affairs, available at: https://www.ethicsandinternationalaffairs.org/2020/

borders-in-the-time-of-covid-19/ (last access: last access: 26 September 2020), 2020b.

Sheffi, Y.: The Power of Resilience, MIT Press, Boston, 2017.

Wallace, R.: Big Farms Make Big Flu, Monthly Review Press, New York, 2016.
Wallace, R. and Wallace, R.: Neoliberal Ebola: Modeling Disease Emergence from Finance to Forest and Farm, Springer, New York, 2016.

Wallace, R., Liebman, A., Chaves, L. F., and Wallace, R.: COVID-19 and Circuits of Capital, Monthly Review, available at: https://monthlyreview.org/2020/05/01/ covid-19-and-circuits-of-capital/\#en35backlink, last access: 20 October 2020.

Wille, C. and Kanesu, R.: Editorial: Borders and COVID-19, Bord. Perspect., 4, 9, https://doi.org/10.25353/ubtr-xxxx-b825-a20b, 2020. 